\title{
Okul Müdürlerinin Yıkıcı Liderlik Davranışlarının Örgütsel Strese
} Etkisi $^{1}$

\author{
Mustafa ÖZGENEL ${ }^{2}$ ve Esra Mavi CANUYLASI ${ }^{3}$
}

\section{$\ddot{O} z$}

$\mathrm{Bu}$ araştırma, okul müdürlerinin yıkıcı liderlik davranışlarının öğretmenlerin örgütsel stresine etkisi olup olmadığını ortaya koymayı amaçlayan bir çalışmadır. Bu amaçla araştırmada, nicel araştırma yöntemlerinden ilişkisel tarama modeli kullanılmıştır. Araştırmanın evrenini 2019-2020 eğitim öğretim yılında İstanbul ilinin Tuzla ilçesinde bulunan devlet okullarında çalışan 4235 öğretmen oluşturmaktadır. Örneklem grubunu ise Tuzla ilçesinde bulunan ilkokul, ortaokul ve liselerde çalışan öğretmenler arasından küme örnekleme yöntemi ile seçilmiş 450 öğretmen oluşturmaktadır. Araştırma sonucunda ortaokul ve lisedeki öğretmenler okul müdürlerini, ilkokul öğretmenlerine göre daha fazla yıkıcı lider olarak algılamıştır. Öğretmenlerin cinsiyetine, eğitim düzeyine ve kıdemine göre yıkıc1 liderlik algıları anlamlı bir farklılık göstermemiştir. Lise öğretmenlerinin örgütsel stres algılarının ilkokul öğretmenlerine göre daha yüksek düzeyde olduğu tespit edilmiştir. Yıkıcı liderlik ve örgütsel stres arasında orta düzeyde pozitif yönde anlamlı bir ilişki bulunmuştur. Ayrıca yıkıcı liderlik davranışları örgütsel stresi \%17 oranında yordamaktadir.

Anahtar Kelimeler: Liderlik, Yıkıcı Liderlik, Stres, Örgütsel Stres

\section{The Effect of Destructive Leadership Behaviors of School Principals' on Organizational} Stress

\begin{abstract}
This study aims to reveal whether the destructive leadership behaviors of school principals affect teachers' organizational stress. For this purpose, relational survey model, one of the quantitative research methods, was used. The universe of the research is 4235 teachers working in public schools in Tuzla district of Istanbul province in 2019-2020 academic year. The sample group consists of 450 teachers selected among teachers working in elementary, secondary and high schools in Tuzla district by cluster sampling method. As a result of the research, teachers in secondary and high school perceived school principals as more destructive leaders than primary school teachers. Destructive leadership perceptions did not differ significantly according to the gender, education level and seniority of the teachers. It has been determined that high school teachers' perception of organizational stress is higher than primary school teachers. A moderately positive correlation was found between destructive leadership and organizational stress. In addition, destructive leadership behaviors predict organizational stress by $17 \%$.
\end{abstract}

Key Words: Leadership, Destructive Leadership, Stress, Organizational Stress

\author{
Atıf İçin / Please Cite As: \\ Özgenel, M., Canuylası, E. M. (2021). Okul müdürlerinin yıkıcı liderlik davranışlarının örgütsel strese etkisi. Manas \\ Sosyal Arastirmalar Dergisi, 10(3), 1652-1664.
}

Geliş Tarihi / Received Date: 10.05.2020

Kabul Tarihi / Accepted Date: 04.05.2021

\footnotetext{
${ }^{1}$ Bu çalışmanın bir bölümü, İZU Sosyal Bilimler Lisansüstü Öğrenci Kongresi’nde sözlü bildiri olarak sunulmuştur.

${ }^{2}$ Doç. Dr., İstanbul Sabahattin Zaim Üniversitesi, İstanbul, Türkiye, mustafa.ozgenel@izu.edu.tr

(iD) ORCID: 0000-0002-7276-4865

${ }^{3}$ Millî Eğitim Bakanlığı, İstanbul, Türkiye, esramavicanuylasi@gmail.com

(iD) ORCID: 0000-0002-2467-8321
} 


\section{Giriş}

Yönetim biliminin tarihsel süreçlerinde, lider ve liderlik kavramlarının oldukça önemli bir yere sahip olmasının yanında, farklı açılardan yapılmış tanımlamaları mevcuttur. Liderlik 20. yüzyılda liderlik üzerine çok sayıda çalışmanın bulunduğu bir fenomen haline gelmiştir. Bass ve Stogdill liderliğe dair çok fazla çalısmanın mevcut olduğunu ve birçok araştırmacının tekrar tekrar liderliği ele aldıklarını belirtmişlerdir (Bass ve Stogdill, 1990, s. 888). Yukl (1989, s. 252); liderliği, gruba ait faaliyetleri ortak bir hedefin gerçekleşmesi amacıyla yönlendirmesi, grubu oluşturan kişilerin üzerinde oluşturduğu, zorlayıcı maksat taşımayan bir etki gücü olarak tanımlamıştır. Liderlik türleri, genel hatlarıyla yapıcı ve yıkıcı liderlik başlıklanı alında ele alınabilir. Yapıcı liderliğin literatürde net bir tanımı olmamakla birlikte, farklı liderlik tanımları içinde bu davranışlara rastlanmaktadır (Selçuk, 2018, s. 31). Yapıcı liderlerin davranışları incelendiğinde astlarılyla ilişkilerinde başarılı ve astlarının düşüncelerini önemseyen liderler oldukları görülmektedir. Bunun yanında rekabeti önemseyen, liderlik sürecinin almak olduğu kadar vermek olduğunu bilen liderlerdir. Kurumun başarısının kurumdaki yapıcı liderlikten geçtiğini bilen ve kurumdaki diğer çalışanlara yardım eden liderler yapıcı liderlerdir. Yapıcı liderler aynı zamanda ekip çalışmasını önemserler. Eleştirinin, esnekliğin ve empatinin yapıcı liderlikte önemli bir yeri vardır (Sevinçok, 2017, s. 157). Yapıcı liderliği, örgüte ve çalışanlara etkileri açısından değerlendirebiliriz. Örgütün hedeflerini ve stratejilerini belirleyebilme, örgütün desteklenmesi yapıcı liderliğin örgütle ilgili yönünü oluşturmaktadır. Çalışanların motivasyonlarını, refah düzeylerini ve işe olan tutumlarını desteklemek ise yapıcı liderliğin çalışanlarla ilgili yönünü oluşturmaktadır. Değişimi yönetmek, teşvik etmek ve ilham verici bir liderlik tarzı benimsemek yapıcı liderlerde bulunan bazı özelliklerdir (Lundmark, Nielsen, Hasson, von Thiele Schwarz ve Tafvelin, 2020, s. 8). Bununla birlikte yapıcı ve yıkıcı liderlik çeşitlerinin birlikte ele alınmasının gerekli olduğu görüşü dile getirilmektedir (Skogstad vd., 2014, s. 6). Elverişli ortamlar, kolektivist kültüreler anlayışlar, güç mesafesi ve orantısız yetki kullanımı yıkıcı liderliğin ortaya çıkışını tetiklemektedir (Holmquist, 2017, s. 134). Yıkıcı liderliğin birçok tanımı yapılmıştır. Bu tanımlar; "liderliğin karanlık yanı" (Conger, 1990, s. 44), "küçük tiranlık" (Ashforth, 1994, s. 756), "suiistimalci veya kötüye kullanılan yönetim" (Tepper, 2000, s. 179; Harris, Kacmar ve Zivnuska, 2007, s. 252), "zaylf liderlik" (Kelloway vd., 2005, s. 89), "caydırıc liderlik" (Thoroughgood, Hunter ve Sawyer, 2011, s. 647), "zehirli (toksik) liderlik" (Wilson-Starks, 2003, s. 1). vb. şeklindedir (Gündüz ve Dedekorkut, 2014, s. 97). Conger'e göre (1990, s. 44) kriz aşamasında kendini kontrol etmekte zorlanan bir lider tipi olan yıkıcı liderler, çalışanlarına gerekli desteği sağlayamadıkları için çalışanlarına ve kuruma zarar verirler. Yapıcı olarak addedilebilecek bazı liderlik tipleri bile zaman zaman yıkıcı liderlik özelliği gösterebilmektedir. Örneğin toplumlar üzerinde etki gücünün yüksek olduğu düşünülen karizmatik liderler zaman zaman y1kıc1 liderlik özelliği gösterebilmektedir (Howell, Avolio, 1992, s. 50). Yıkıc1 Liderlik (Uymaz, 2013, s. 38), Toksik Liderlik (Çelebi vd., 2015, s. 250) ve "İş̧ Yerinde Karanlık Liderlik" (Başar, Sığrı ve Basım, 2016, s. 67) adıyla birçok alt boyutta araştırılması yapılan karanlık liderlik, kavram olarak literatürde yeni sayılabilecek bir liderlik alanı olarak görülmektedir.

Toksik liderlik yaklaşımını, etkili çalışmalarıyla biraz daha öne taşıyan Padilla ve arkadaşları karanlık liderliğin etkileşime dayalı olarak açıklanmasını uygun görmüş ve yıkıcı liderlik kavramına tanımlama yapmışlardır. Zehirli üçgen adını verdikleri çevre, yıkıcı lider ve takipçi ögelerinin temel dayanak olduğu yapıyı oluşturmuşlardır (Padilla, 2007, s. 180). Padilla ve arkadaşlarına (2007, s. 179) göre yıkıcı liderin beş davranışı bulunmaktadır:

- Yıkıcı liderler olumlu bir etki, sadakat veya ikna yerine zorbalı̆gı ve manipülasyonu kullanırlar.

- Yıkıcı liderler bencil bir anlayışla kurumun ve kurum çalısanlarının isteklerini ve ihtiyaçlarını görmezden gelerek kendilerine odaklanırlar.

- Yıkı1 liderlerin yıkıcı davranışları çalışanların ve kurumunun hedeften uzaklaşmasına neden olur.

- Yıkı1 liderlerin faaliyetleri her zaman tamamen yıkıcı olmaz. Yıkıcı liderliğin olumsuz sonuçları olduğu gibi olumlu sonuçları da vardır.

- Yıkı1 örgüt faaliyetlerinde etkili olan sadece liderler değildir. Elverişli ortamlar ve yıkıcı liderin takipçileri de yıkıcı örgütsel faaliyetlerde rol oynar.

Yıkıcı lider davranışları; liderin örgütün hedeflerini, sahip olduğu kaynak imkânlarını, işin refah düzeyini aşağı çeken ve örgütün çıkarlarını ihmal ve ihlal etmekten kaçınmayan düzenli ve tekrarlı yapılagelen lider davranışları olarak tanımlanmışıtır (Einarsen, 2007, s. 208). Conger'e göre (1990, s. 44) lider kişisel kazanç çabasıyla hareket ettiğinde çalısanlarına ve örgüte zarar vermektedir. Yıkıcı yöneticilik, 
yöneticinin tutumları ve işlevsel olmayan kişilik özellikleri sebebiyle; kuruluşlarla ilişiği olan kişilere yönelik, kalıcı olumsuz yaşantı izleri bıraktıkları süreç anlamına gelmektedir (Lipman-Blumen, 2005, s. 29). Einarsen (2007, s. 208) yıkıc yöneticiliğin sadece kişilere zarar vermekle kalmayıp, kurum menfaatlerini de tehlikeye attığını savunmuştur. Okul ortamlarının yönetici lider konumunda olan müdürler, okuldaki işleyen sürecin sorumlusu olan kimselerdir. Yöneticinin pozitif veyahut negatif yönetme davranışlarında bulunması durumundan, birincil olarak etkilenmesi beklenen kişiler, eğitim sürecinin üst düzey sorumlusu olan ögretmenlerdir (Sarıaslan Eyiol, 2014, s. 1). Yıkıcı liderliğin iki temel sorunu vardır; birincisi yıkıc1 liderlik davranışlarının sonuçlarının ve maliyetlerinin oldukça ağır olması ikincisi ise yıkıcı liderliğin güçlü kurumlarda yaygınlık göstermesidir (Schyns ve Schilling, 2012, s. 138).

Örgütü oluşturan kişilerin maruz kaldığı yıkıcı liderlik davranışları; çok geniş bir yelpazede ele alınabilmekle birlikte çalışanlarına kötü davranan, bencil, benmerkezci olup kendi günlük rutini dışına çıkmayan ve davranışlarının örgüt çalışanlarının üzerindeki etkisini önemsemeyen davranışlar da yıkıcı liderlik davranışı olarak kabul edilebilir (Chen, Mao, Hsieh, Liu ve Yen, 2013, s.89). Kötü yönetim uygulamaları, artan iş yükü, kötü iletişim ve iş güvenliği strese neden olan faktörlerin başında gelmektedir (Lewig ve Dollard, 2001, s. 187). İyi anlaşılamamış bir insan profilinin örgütteki devamlılığ1 sağlama ve hedeflere ulaşmadaki gücü yetersiz olacağından örgütsel sürecin öncelikle insanı iyi anlama fikrine odaklanması gerekmektedir.

Okul yöneticilerinin yıkıcı davranışları arasında; öğrenci ve işgörene adil olmayan, fiziksel ve söze dayalı taciz gibi alenen ortaya çıkan ihlal içerikli tutumlar sayılmıştır (Pehlivan, 1998). Yıkıcı lider davranışları, birbirine düşmanca tutumlarla yaklaşan çalışanları ve gergin çalışma ortamlarını doğurmuştur. Çoğu zaman örgüt çalışanları farkında olmadan lider davranışlarıyla ilgili hislere sahip olmakta ama hissettiklerini tam olarak adlandıramamaktadırlar. Bunun yanında duygularına göre hareket eden bireyler bunu psikolojik bir savunma ihtiyacı olarak gerçekleştirmektedirler (Westen, 1998, s. 343). Yıkıcı liderler çalışma ortamlarında yıkıcı davranışlarda bulunarak toksik bir ortamın oluşmasına neden olabilirler (James ve LeBerton, 2010, s. 34).

Örgüt, bir ihtiyacın giderilmesi amacıyla birden fazla kişinin bir arada bulunup ortak amaçlar için beraber hareket ettikleri, topluma dair aç1k sistem olarak ifade edilebilir (Pehlivan, 1993). Yıkıcı lider iktidarının devamını sağlamak için örgüt çalışanlarının güç kazanmasına, gelişimini arttırmasına ve süreçlere dahil olmasının önünde engel olur (Conger, 1990, s. 44). Örgüt içerisinde, yıkıcı liderlik davranışlarını sergileyen liderler vardır. Eğitim örgütleri girdisi insan olması ile önemini korur ve tam da bu yanıyla diğer örgüt anlayışlarından kendini ayırmaktadır. Bu özelliği taşıması, eğitim örgütlerinin iş görü anlayışını ve sınırını artırmaktadır. Bu iş görülerin yerine getirilmesi ise stresten uzaklaştırılmış okul ortamlarında görevlerini yerine getiren öğretmenleri zorunlu kılmaktadır (Aslan, 2018, s. 351). Yıkıcı davranışlar sadece psikolojik boyutta kalmayan, bireyde fiziksel problemleri de beraberinde getiren stresi oluşturmaktadır. Stres genel bir tanımıyla, insanlığın mutluluğu ve huzuru adına kriz içeren bir durum olarak kabul edilen, durumlara yeterli özenin gösterilmemesi, net olmayan fiziksel ve ruhsal tepkilere denir (Şimşek ve Çelik, 2013). Bir başka tanımla stres; bireyin ihtiyaçlarını terk etmek zorunda kalması ya da bir tepki vermek zorunda bırakılmasına, bireyin içsel ve dişsal kaynaklı gerilimlerine neden olan bir güçtür (Başaran, 1991). Bireylerin baş ettiği stres kaynakları olduğu gibi, örgütlerin de mücadele ettiği stres faktörleri bulunmaktadır. Stres, öğretmenin kendini başarma kapasitesini düşürmekte ve eğitim kurumları için problem olmaktadır (Işıkhan, 2004). Ayrıca literatürde örgütsel stresle nasıl mücadele edileceği (Eriş ve Yücel, 2018, s. 317), örgütsel stresin çalş̧an performansı üzerine etkisi (Yaman, 2019, s. 161), örgütsel stresin iş gören performansı üzerinde etkileri ve stres yönetimi (Örnek, 2017) adı altında ele alınmış bazı araştırmalar olduğu saptanmıştır. Bu araştırmanın lider davranışları ve örgüt stresi arasındaki ilişkiye yer veren sınırlı sayıda çalışma olması nedeniyle literatüre katkı sağlaması beklenmektedir.

Stres kavramında bahsettiğimiz gibi örgütsel streste de genel bir tanımlama yapılamamışır (Poyraz, 2009 , s. 3). İşs ortamındaki stres kaynakları ve gerginlik içeren tutumları kapsayan ve sosyal bir gerçek haline gelen stres, iş ortamı ve işçi arasındaki uyumsuzluğu ifade eder (Lewig ve Dollard, 2001, s. 180). Örgütsel stres, örgüt ortamındaki çeşitli durum ve olayların iş gören tarafindan stres kaynağ1 olarak alg1lanmasıyla başlamaktadır (Ertekin, 1993). Örgütün veriminin düşmesine sebep olan temel sorunun stres olduğu düşünülebilir (Cemaloğlu, 2007, s. 77). Çizgileri belli olmayan roller, rollerin çatışmaya dönüşen dağılımları, iş yükünün az ya da çok olması, iletişimin anlaş1ır bir dile sahip olmaması, etki gücü dağılmış bir kariyer yönetimi, mesleki farkll1ıklar ve performans ölçümleri stresi oluşturan etmenler arasında sıralanabilir (Akgemci, 2001, s. 303). Buradan anlaşıldığ1 gibi yönetim tarzı, örgütsel stresin baş faktörlerindendir. 
Yıkıcı lider davranışlarını ele aldığımızda örgütsel stresi oluşturan faktörler ile güçlü bir bağı olduğu düşünülebilir. Yıkıcı nitelikte davranışlarda bulunan liderin varlığını tespit edebilmek için örgütü oluşturan kişilerin bu davranışları fark etmesi gerekir (Uymaz, 2013, s. 40). Yıkıcı lider davranışına maruz kalan bireyler, yıkık kimlik psikolojisi ile yıkıcı faaliyetlerde bulunmaktadır. Bu araştırmada 'Yıkıcı lider davranışlarının, örgütsel strese bir etkisi var mıdır?’ sorusunun cevabı aranmaktadır.

1. Okul müdürlerinin yıkıcı liderlik davranışları ve örgütsel stres ne düzeydedir?

2. Okul müdürlerinin yıkıcı liderlik davranışları ve örgütsel stres, öğretmenlerin cinsiyetine, okul kademesine, mesleki kıdemine ve öğrenim durumuna göre anlamlı bir farklılık göstermekte midir?

3. Okul müdürlerinin yıkıcı lider davranışları ile örgütsel stres arasında anlamlı bir ilişki bulunmakta midir?

4. Okul müdürlerinin yıkıcı lider davranışlarının örgütsel strese etkisi var mıdır?

\section{Yöntem}

\section{Araştırmanın Modeli}

$\mathrm{Bu}$ araştırma, okul müdürlerinin yıkıcı liderlik davranışlarının öğretmenlerin örgütsel stresine etkisi inceleyen bir çalısmadır. Bu amaçla ilişkisel tarama modeline göre yürütülmüştür. İlişskisel tarama modeli, iki veya daha fazla değişken arasındaki ilişkinin incelendiği araştırma modelleridir (Büyüköztürk vd., 2012, s. 184).

\section{Evren ve Örneklem}

Araştırmanın evrenini 2019-2020 eğitim öğretim yllında İstanbul ilinin Tuzla ilçesinde devlet okullarında görev yapan 4.235 öğretmen oluşturmaktadır. Çalışmanın örneklemini İstanbul'un Tuzla ilçesindeki ilkokul, ortaokul ve liselerde çalışan öğretmenler arasında küme örnekleme yöntemi ile seçilmiştir. Örneklemi ise küme örnekleme yöntemi ile seçilen 450 öğretmen oluşturmuştur. Örneklem büyüklügü belirlenirken $\% 5$ kabul edilebilir hata oranı ve $\% 95$ güven seviyesi kriter olarak alınarak küme örnekleme yöntemi kullanılmıştır. Küme örnekleme yöntemi ile geniş yer kaplayan evrene ulaşmak kolaylaşırken ve araştırmacının evrene ulaşım maliyeti düşecek, araştırmacının verilere dair kontrolü artacak ve araştırmacıya vakit kazandıracaktır (Creswell ve Clark, 2016 Akt: Baltacı, 2018, s. 243).

Tablo 1. Callsma Grubuna Ait Demografike Bilgiler

\begin{tabular}{llcc}
\hline Değişkenler & Gruplar & f & Yüzde \\
\hline \multirow{2}{*}{ Cinsiyet } & Kadın & 320 & 71.1 \\
& Erkek & 130 & 28.9 \\
\hline \multirow{3}{*}{ Kidem } & 5 yll ve altı & 78 & 17.3 \\
& $6-10$ yll & 140 & 31.1 \\
& $11-15$ yll & 93 & 20.7 \\
& $16-20$ yll & 81 & 18 \\
\multirow{2}{*}{ Okul Türü } & 21 yll ve üstü & 58 & 12.9 \\
& İlkokul & 156 & 34.7 \\
Eğitim Düzeyi & Ortaokul & 128 & 28.4 \\
\hline Toplam & Lise & 166 & 36.9 \\
\hline
\end{tabular}

Tablo 1'de görüldüğü üzere örneklem grubunu oluşturan öğretmenlerin 320'si (\%71,1) kadın, 130'u (\%28.9) erkektir. 78’i (\%17,3) 5 yll ve altı, 140’1 (\%31,1) 6-10 yıl arası, 93’ü (\%20,7) 11-15 yll arası, 81 ‘i $(\% 18,0)$ 16-20 y1l aras1, 58’i $(\% 12,9) 21$ yil ve üzeri kıdeme sahiptir. Öğretmenlerin 156’s1 (\%34,7) ilkokul, 128 'i $(\% 28,4)$ ortaokul, 166's1 $(\% 36,9)$ lise düzeyinde bir okulda görev yapmaktadır. Öğretmenlerden 387'si (\%86) lisans ve 63’ü (\%14) lisansüstü eğitim almıştır

\section{Veri Toplama Araçları}

Bu araştırmada okul müdürlerinin algılanan yıkıcı liderlik davranışlarını belirlemek için Uymaz (2013) tarafindan geliştirilen Yıkıcı Liderlik Ölçeği; örgütsel stres düzeyini belirlemek için ise Yıldırım ve arkadaşlarının (2011) uyarlama çalışması yaptıkları Örgütsel Stres Ölçeği kullanılmıştır. Ölçeklerin kullanımı için araştırmacılardan ölçek izinleri alınmıştır. Ölçme araçları, 2019-2020 eğitim-öğretim yılında 
1. Yarıyıl döneminde araştırmacı tarafindan, örneklemi oluşturan Tuzla ilçesindeki okullara uygulanmıştır. Dağıtılan 700 ölçekten 466 adet ölçek değerlendirilmeye alınmış ve 16 ölçek ise yanlış işaretleme ve boş bırakılan kısımlar sebebiyle analiz dışında bırakılmıştır. Ölçekler uygulanırken araştırmanın amacı açıklanmış olup gönüllü katılım sağlanmıştır. Zaman sınırlaması uygulanmamış, katılımcıların hassasiyetlerine özen gösterilmiştir. Ölçek araştırmacı tarafından uygulanmıştır. Uygulama sürecinde yeterli bilgiye sahip araştırmacı gözlemci olarak ölçek uygulama sürecine katılmıstır. Tam doldurulmayan ve hata olduğu düşünülen anketler değerlendirmeye alınmamıştır.

\section{Verilerin Analizi}

Yapılan istatistiksel işlemlerdeki analizleri SPSS istatistik paket programı ile yapılmıştır. Yıkıcı liderlik ile örgütsel stres arasındaki ilişkiyi belirlemek için korelasyon; yıkıcı liderlik ile örgütsel stres düzeyinin değişkenler açısından farklılık oluşturup oluşturmadığını görmek için one-way ANOVA; yıkıcı liderlik ile örgütsel stresin cinsiyete ve eğitim durumuna göre değişip değişmediğini analiz etmek için $t$ testi kullanılmıştır. ANOVA testinde anlamlı farklı1ık ortaya çıktığında farklılığın hangi gruplar arasında olduğunu belirlemek amaciyla post hoc Scheffe testi (grupların varyansları homojen) yapılmıştır.

\section{Bulgular}

Yıkıcı Liderlik Ölçeğinin ve Örgütsel Stres Ölçeğinin ortalamaları, standart sapmaları, basıklık, çarpıklık ve güvenirlik değerleri Tablo 2'de verilmiştir.

Tablo 2. Yıkıcı Liderlik ve Örgütsel Stres Ölçeklerinin Betimsel Değerleri

\begin{tabular}{lcccccc}
\hline Değişkenler & N & AO & S & Skewness & Kurtosis & $\begin{array}{c}\text { Cronbach } \\
\text { Alpha (a) }\end{array}$ \\
\hline Yılkıı Liderlik & 450 & 3.32 & .791 & .752 & .348 & .970 \\
\hline Örgütsel Stres & 450 & 1,99 & .392 & .327 & .814 & .670 \\
\hline
\end{tabular}

Tablo 2 incelendiğinde basıklık ve çarpıklık değerlerinin -1 ve +1 arasında olduğu görülmüş ve verilerin normal dağılım gösterdiği sonucuna ulaşılmıştır. Öğretmenlerin algılarına göre okul müdürlerinin yıkıcı liderlik davranışları ve örgütsel stres düzeylerinin cinsiyete göre t-testi sonuçları Tablo 3 'te verilmiştir.

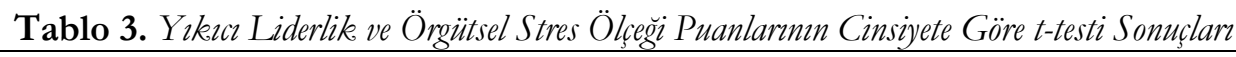

\begin{tabular}{lllllcll}
\hline Değişkenler & Gruplar & $\mathbf{N}$ & AO & S & t & df & p \\
\hline Yikıcı & Kadın & 320 & 1,97 &, 76 & \multirow{2}{*}{1,181} & \multirow{2}{*}{448} & \multirow{2}{*}{, 238} \\
Liderlik & Erkek & 130 & 2,06 &, 86 & & & \multirow{2}{*}{, 897} \\
\multirow{2}{*}{ Örgütsel Stres } & Kadın & 320 & 2,63 &, 37 & \multirow{2}{*}{, 130} & \multirow{2}{*}{448} & \\
& Erkek & 130 & 2,63 &, 42 & &
\end{tabular}

Tablo 3 'teki bulgular incelendiğinde öğretmenlerin yıkıcı liderlik $\left(\mathrm{t}_{[448]}=-1,181 ; \mathrm{p}>, 05\right)$; ve örgütsel stres algıları $\left(\mathrm{t}_{[448]}=, 130 ; \mathrm{p}>, 05\right)$ öğretmenlerin cinsiyetlerine göre anlamlı farkllı, oluşturmadığ1 görülmektedir. Öğretmenlerin yıkıcı liderlik ve örgütsel stres algılarının eğitim durumuna göre t-testi sonuçları Tablo 4'te verilmiştir.

Tablo 4. Yıkıcı Liderlik ve Örgütsel Stres Ölçeği Puanlarnm Eğitim Durumuna Göre t-testi Sonuclar

\begin{tabular}{llcccccc}
\hline Değişkenler & Gruplar & $\mathbf{N}$ & AO & S & t & df & p \\
\hline \multirow{2}{*}{ Yıkıcı Liderlikk } & Lisans & 387 & 1.97 &, 77 & \multirow{2}{*}{$-1,564$} & \multirow{2}{*}{448} & \multirow{2}{*}{, 119} \\
& Lisansüstü & 63 & 2.14 &, 87 & & \multirow{2}{*}{, 094} \\
\hline \multirow{2}{*}{ Örgütsel Stres } & Lisans & 387 & 2.62 &, 38 & $-1,681$ & \multirow{2}{*}{448} & \\
& Lisansüstü & 63 & 2.71 &, 41 & & \\
\hline
\end{tabular}

Tablo 4'teki bulgular incelendiğinde öğretmenlerin yıkıcı liderlik ( $\left.\mathrm{t}_{[448]}=-1,564 ; \mathrm{p}>, 05\right)$; ve örgütsel stres algilarının $\left(\mathrm{t}_{[448]}=-1,681 ; \mathrm{p}>, 05\right)$ öğretmenlerin eğitim durumuna göre anlamlı farklılık oluşturmadı̆̆1 görülmektedir. Öğretmenlerin örgütsel stres ve yıkıcı liderlik algılarının okul kademelerine göre değişkenlik gösterip göstermediği sorusuna yanıt verebilmek için uygulanan ANOVA testi sonuçları Tablo 5'te verilmiştir.

Tablo 5. Örgütsel Stres ve Yıkıc Liderlik Puanlarmmn Okul Kademesine Göre ANOVA Sonuclar

\begin{tabular}{|c|c|c|c|c|c|c|c|c|c|c|c|}
\hline $\begin{array}{l}\text { B.'l1 } \\
\text { Değ. }\end{array}$ & Okul Türü & $\mathbf{N}$ & AO & $\mathbf{S}$ & $\begin{array}{l}\text { Varyansın } \\
\text { Kaynağ1 }\end{array}$ & KT & df & KO & F & $\mathrm{p}$ & Fark \\
\hline \multirow{2}{*}{ केष } & A-İlkokul & 156 & 2.57 & .38 & G. Aras 1 & 1.151 & 2 & .576 & \multirow{2}{*}{3.779} & \multirow{2}{*}{.024} & \multirow{2}{*}{$\mathrm{A}<\mathrm{C}$} \\
\hline & B-Ortaokul & 128 & 2.64 & .39 & G. İçi & 68.094 & 447 & .152 & & & \\
\hline
\end{tabular}




\begin{tabular}{|c|c|c|c|c|c|c|c|c|c|c|c|}
\hline & C-Lise & 166 & 2.68 & .39 & Toplam & 69.245 & 449 & & & & \\
\hline & Toplam & 450 & 2.63 & .39 & & & & & & & \\
\hline \multirow{3}{*}{$\begin{array}{l}: 0 \\
: 0 \\
0 \\
0\end{array}$} & A-İlkokul & 156 & 1,75 &, 79 & G. Aras 1 & 16,718 & 2 & 8,359 & \multirow{3}{*}{14,11} & \multirow{3}{*}{,000 } & \multirow{3}{*}{$\mathrm{A}<\mathrm{B}, \mathrm{C}$} \\
\hline & B-Ortaokul & 128 & 2,01 &, 74 & G. İçi & 264,80 & 447 & ,592 & & & \\
\hline & $\begin{array}{l}\text { C-Lise } \\
\text { Toplam }\end{array}$ & $\begin{array}{l}166 \\
450\end{array}$ & $\begin{array}{l}2,21 \\
1,99\end{array}$ & $\begin{array}{l}, 76 \\
79\end{array}$ & Toplam & 281,52 & 449 & & & & \\
\hline
\end{tabular}

Tablo 5'teki bulgular incelendiğinde yıkıcı liderlik davranışlarının ve örgütsel stresin çalsşılan okul kademesine göre farklılaştığı tespit edilmiştir. Hangi gruplar arasında anlamlı farklılık olduğunu belirlemek amaciyla post hoc Scheffe testi yapılmıştır. İlkokulda çalışan öğretmenlerin örgütsel stres düzeyleri $(\mathrm{AO}=2,57)$, lise öğretmenlerine $(\mathrm{AO}=2.68)$ göre daha düşük düzeyde bulunmuştur. Ayrıca ilkokulda görev yapan öğretmenler okul müdürlerinin yıkıcı liderlik davranışlarını $(\mathrm{AO}=1.75)$, ortaokul $(\mathrm{AO}=2.01)$ ve lise $(\mathrm{AO}=2.21)$ kademelerinde görev yapan öğretmenlere göre daha düşük düzeyde algılamaktadır. Başka bir ifadeyle okul kademesi ilkokuldan ortaokul ve liseye doğru ilerledikçe öğretmenlerin örgütsel stres ve okul müdürlerinin yıkıcı liderlik davranışlarına yönelik algıları da artmaktadır.

Öğretmenlerin örgütsel stres ve yıkıcı liderlik alg1larının kıdemlerine göre farklıllk gösterip göstermediğini öğrenebilmek için yapılan ANOVA Testi sonuçları tablo 6'da verilmiştir.

Tablo 6. Örgütsel Stres Ölçeği Puanlarmın Kıdeme Göre ANOVA Sonucları

\begin{tabular}{|c|c|c|c|c|c|c|c|c|c|c|c|}
\hline $\begin{array}{l}\text { B.11 } \\
\text { Değ. }\end{array}$ & Sinıf & $\mathbf{N}$ & AO & $\mathbf{S}$ & $\begin{array}{l}\text { Varyansın } \\
\text { Kaynağ1 }\end{array}$ & KT & sd & KO & $\mathbf{F}$ & $\mathrm{p}$ & Fark \\
\hline \multirow{6}{*}{ 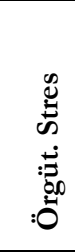 } & A-5 y1l ve alt1 & 78 & 2.44 & .36 & G. Aras 1 & 3.96 & 4 & .990 & \multirow{6}{*}{6.75} & \multirow{6}{*}{.000} & \multirow{6}{*}{$\begin{array}{l}\mathrm{B}>\mathrm{A} ; \\
\mathrm{C}>\mathrm{A} ; \\
\mathrm{D}>\mathrm{A} ; \\
\mathrm{E}>\mathrm{A}\end{array}$} \\
\hline & B-6-10 & 140 & 2.69 & .36 & G. İçi & 65.284 & 445 & .147 & & & \\
\hline & C-11-15 & 93 & 2.62 & .35 & Toplam & 69.245 & 449 & & & & \\
\hline & D-16-20 & 81 & 2.72 & .40 & & & & & & & \\
\hline & E-21+ & 58 & 2.65 & .44 & & & & & & & \\
\hline & Toplam & 450 & 2.63 & .39 & & & & & & & \\
\hline \multirow{6}{*}{ 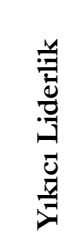 } & A-5 yil ve altı & 78 & 1.81 & .67 & G. Aras1 & 4.346 & 4 & 1.086 & \multirow{6}{*}{1.744} & \multirow{6}{*}{.139} & \multirow{6}{*}{---} \\
\hline & B-6-10 & 140 & 2.07 & .79 & G. İçi & 277.177 & 445 & .623 & & & \\
\hline & C-11-15 & 93 & 2.05 & .86 & Toplam & 281.523 & 449 & & & & \\
\hline & D-16-20 & 81 & 2.05 & .76 & & & & & & & \\
\hline & E-21+ & 58 & 1.91 & .81 & & & & & & & \\
\hline & Toplam & 450 & 1.99 & .79 & & & & & & & \\
\hline
\end{tabular}

Tablo 6'e göre öğretmenler tarafindan algılanan örgütsel stres öğretmenlerin kıdemlerine göre anlamlı bir farklılık bulunmaktadır $(\mathrm{F}=6,75 ; \mathrm{p}<, 05)$. Hangi gruplar arasında anlamlı farklılık olduğunu belirlemek amacıyla post hoc Scheffe testi yapılmıştır. 5 yll ve altı mesleki kıdeme sahip öğretmenlerin örgütsel stres düzeyleri $(\mathrm{AO}=2,44), 6-10$ yll $(\mathrm{AO}=2,69), 11-15$ yll $(\mathrm{AO}=2,62), 16-20$ yll $(\mathrm{AO}=2,72)$ ve 21 yll ve üstü $(\mathrm{AO}=2,65)$ mesleki kıdeme sahip öğretmenlerin örgütsel stres düzeylerine göre daha düşük olduğu görülmüştür. Okul müdürlerinin yıkıcı liderlik davranışları öğretmenlerin kıdemlerine göre anlamlı farklılık göstermemektedir ( $\mathrm{F}=1.744$; $\mathrm{p}>.05)$.

Okul müdürlerinin yıkıcı liderlik davranışları ile öğretmenlerin örgütsel stres düzeyleri arasında bir ilişkinin olup olmadığını ortaya çıkarmak maksadıyla yapılan korelasyon analizi tablo 7'de verilmiştir.

Tablo 7. Yıkıcı Liderlik Davranıslar ile Örgütsel Stres Arasındaki Korelasyon Analizi

\begin{tabular}{llc}
\hline Değişkenler & & Örgütsel Stres \\
\hline \multirow{3}{*}{ Y1kıcı Liderlik } & $\mathrm{r}$ &, 416 \\
& $\mathrm{p}$ & .000 \\
& $\mathrm{~N}$ & 450 \\
\hline
\end{tabular}

**Korelasyon 0,01 düzeyinde anlamlıdır.

Tablo 7'de verilen korelasyon analizi bulgularına göre okul müdürlerinin yıkıcı liderlik davranışları ile örgütsel stres arasında orta düzeyde ve pozitif (olumlu) yönde anlamlı bir ilişki bulunmaktadır ( $\mathrm{n}=450$; $\mathrm{R}=.416 ; \mathrm{p}<.000)$.

Okul müdürlerinin yıkıcı liderlik davranışlarının, öğretmenlerin örgütsel stres algılarını yordayıp yordamadığını belirlemek amacıyla yapılan regresyon analizi sonuçları Tablo 8'de verilmiştir. 
Tablo 8. Yıkıcı Liderlik Davranıslarmm Öroütsel Stresini Yordamasına İlișin Regresyon Analizi Sonuclar

\begin{tabular}{|c|c|c|c|c|c|c|c|c|c|c|}
\hline $\begin{array}{l}\text { Bağımsız } \\
\text { Değişken }\end{array}$ & $\begin{array}{l}\text { Bağımli } \\
\text { Değişken }\end{array}$ & B & $\begin{array}{l}\text { Std. } \\
\text { Hata }\end{array}$ & $(\beta)$ & $\mathrm{t}$ & $\mathrm{p}$ & $\mathbf{R}$ & $\mathbf{R}^{2}$ & $F$ & $p$ \\
\hline Sabit & \multirow[b]{2}{*}{$\begin{array}{l}\text { Örgütsel } \\
\text { Stres }\end{array}$} & 2.223 & .046 & & 48.53 & .000 & \multirow[b]{2}{*}{.416 } & \multirow[b]{2}{*}{. 173} & \multirow[b]{2}{*}{94.024} & \multirow[b]{2}{*}{.000} \\
\hline $\begin{array}{l}\text { Yikıc1 } \\
\text { Liderlik }\end{array}$ & & 207 & .021 & .416 & 9.69 & .000 & & & & \\
\hline
\end{tabular}

Tablo 8 incelendiğinde okul müdürlerinin yıkıcı liderlik davranışlarının örgütsel stresi yordamasına yönelik yapılan regresyon analizi ele alındığında bağımsız değişken olan yıkıcı liderlik davranışları ile bağımlı değişken olan örgütsel stres arasında pozitif yönde ve orta düzeyde anlamlı ilişki bulunmaktadır. Okul müdürlerinin yıkıcı liderlik davranışlarının, örgütsel stresi anlamlı bir şekilde yordadığı sonucuna ulaşılmıştır. Başka bir ifadeyle okul müdürlerinin yıkıcı liderlik davranışları, örgütsel stresteki toplam varyansın \%17'sini açıklamaktadır $\left(\beta=.416 ; \mathrm{R}^{2}=.173 ; \mathrm{F}=94.024 ; \mathrm{p}<.000\right)$. Okul müdürlerinin yıkıcı liderlik davranışları arttıkça, öğretmenlerin örgütsel stres düzeyinin de arttı̆̆ını düşünmektedir.

\section{Tartışma, Sonuç ve Öneriler}

$\mathrm{Bu}$ araştırma nicel araştırma modellerinden ilişkisel tarama modeline göre yürütülmüsş, 450 öğretmene ulaşılmış, okul müdürlerinin yıkıcı liderlik davranışlarının örgütsel stres üzerindeki etkisi incelenmiştir. Yıkıcı liderlik davranışları ve örgütsel stres algılarının cinsiyet, eğitim düzeyi, okul kademesi ve mesleki kıdem gibi farklı değişkenler açısından farklılık gösterip göstermediği araştırlmıştır. Araştırmanın ilk bulgularına göre öğretmenlerin örgütsel stres düzeyi "orta", yıkıcı liderlik düzeyi ise "dïssük" seviye gerçekleşmiştir.

Öğretmenlerin örgütsel stres algisının "orta” düzeyde olduğu görülmüştür. Yolbakan'ın (2019, s. 63) yapmış olduğu araştırmada da "orta" düzeyde örgütsel stres bulgusuna ulaşılmıştır. Sirke'nin (2016, s. 70), Baytak'ın (2015, s. 74) ve Moğul'un (2014, s. 56) çalışmaları da bu yöndedir. Dak (2019, s. 129-130) ise öğretmenlerin örgütsel stres düzeyini "yülksek" düzeyde belirlemiştir. Örgütsel stresle ilgili alanyazın incelendiğinde öğretmenlerin örgütsel stres düzeylerinin orta ve yüksek düzeyde olduğu görülmektedir.

Öğretmenlerin örgütsel stres algilarının eğitim durumuna göre anlamlı bir farklılık bulunmamıştır. Sirke (2016, s. 71) yaptığ araştırmada aynı sonucu işaret etmiştir. Karadavut'a (2005) göre yüksek lisans eğitimi alan eğitimciler, lisans eğitimi alan öğretmenlere göre daha çok örgütsel stres faktörü yaşadıklarını düşünmektedirler. Yolbakan'in (2019, s. 66) yapmış olduğu çalışmaya göre öğretmenlerin öğrenim durumları arttıkça örgütsel stres düzeylerinin arttığı sonucuna ulaşılmıştır. Öğrenim durumu yüksek lisans düzeyinde olan öğretmenlerin farkındalık düzeylerinin artması, stres faktörlerinin daha çok farkında olmaları, daha mükemmeliyetçi olmaları, iş tatmini ve doyumu düzeylerinin daha yüksek olması böyle bir sonucu doğurmuş olabilir.

Öğretmenlerin örgütsel stres algıları, cinsiyetlerine göre anlamlı bir farklılık oluşturmamıştır. Öğretmenlerin algıladıkları örgütsel stres ortalamalarına bakıldığında kadın öğretmenlerin örgütsel stres düzeylerinin ve erkek öğretmenlerin örgütsel stres düzeylerinin aynı olduğu sonucuna ulaşılmıştır. Bu sonuca bakıldığında örgütsel stresi oluşturan faktörlerin kadın ve erkek öğretmenler üzerinde herhangi bir farklılık oluşturmadığı görülmektedir. Kadın ve erkek öğretmenlerin örgütsel stres düzeylerinin yakın olması cinsiyetin örgütsel stres üzerinde herhangi bir etkisinin bulunmadığını göstermektedir. Özbaş'ın (2019, s. 51) yaptığı çalışmaya göre öğretmenlerin stres kaynaklarının cinsiyet değişkeni açısından değişmediği bulgusuna ulaşıllmıştır. Gök (2009, s. 444), Sirke (2016, s. 71) ve Merkan (2011, s. 90) yapmış oldukları araştırmalarda aynı sonuca ulaşmışlardır. Bununla birlikte bazı araştırmalarda kadın öğretmenlerin stres düzeylerinin erkek öğretmenlere göre daha yüksek olduğu görülmektedir. Yolbakan (2019, s. 65) yapmış olduğu çalısmada kadın öğretmenlerin örgütsel stres düzeylerinin erkek öğretmenlerden yüksek olduğu sonucuna ulaşmışır. Karadavut'un (2005) yapmış olduğu çalışmaya göre kadın öğretmenlerin stres düzeyleri, erkek öğretmenlerin stres düzeyine göre daha yüksek bulunmuştur.

Araştırmanın sonuçlarında öğretmenlerin kıdemlerine göre örgütsel stres düzeylerinin farklılaşıp farklılaşmadığına bakılmıştır. Elde edilen sonuçlara göre 5 yıl ve altı kıdeme sahip öğretmenlerin örgütsel stres algilarının, 6-10 yıl, 11-15 yıl, 16-20 yıl, 21 ve üzeri yıl kıdeme sahip öğretmenlere göre düşük olduğu sonucuna ulaşılmıştır. Yolbakan'ın (2019, s. 65) yapmış olduğu araştırmada da paralel sonuçlar elde edilmiş, en yüksek örgütsel stres alg1sı 6-10 yıl kıdeme sahip öğretmenlerde görülmüştür. Karadavut (2005), Poyraz (2009, s. 90), Merkan (2011, s. 90), Moğul (2014, s. 56), Sirke (2016, s. 71) ve Aslan ve Bakıroğlu (2018, s. 360) kıdemin örgütsel stres üzerinde belirleyici olmadı̆̆ı sonucuna ulaşmışlardır. Bu çalışmada en düşük örgütsel stres düzeyinin 5 yll ve altı kıdemde bulunan öğretmenlere tespit edilmesinin nedenleri 
düşünüldüğünde, mesleki yıpranmışlığın az olması, stresi oluşturan faktörlerin farkına varamama, mesleğe yeni başlamış olmayla birlikte stres oluşturan yönetici davranışlarına daha pozitif yaklaşma gibi durumlar sayllabilir.

Çalıştı̆̆1 okul kademesine göre örgütsel stres anlamllık derecesinin ortaya konması için yapılan analizin sonuçları incelendiğinde çalışllan okul kademesinin örgütsel stres alg1sı üzerinde önemli bir etkisi olduğu sonucuna ulaşılmıştır. İlkokul öğretmenlerin örgütsel stres düzeyinin, ortaokul öğretmenlerinden, ortaokul öğretmenlerinin örgütsel stres düzeyinin de lise öğretmenlerinin örgütsel stres düzeyinden düşük olduğu sonucuna ulaşılmışır. Bu sonuca göre lise öğretmenlerinin örgütsel stres faktörlerine daha çok maruz kaldığı düşünülebilir. Bununla birlikte ilkokul öğretmenlerin ilgilendikleri öğrenci sayısının az olması, ortaokul ve lise öğretmenlerinin daha çok öğrenciyle ilgilenmek zorunda olmalarının ve öğrencilerin ergen davranışlarına maruz kalmalarının okul kademeleri arasındaki örgütsel stres düzeyinin farklılaşmasında etkili olduğu düşünülebilir. Yolbakan'ın (2019, s. 66) çalışmasına göre ise örgütsel stres düzeyi en yüksek olan grup ortaokul öğretmenleri olmuştur. Özbaş'ın (2019, s. 51) çalışmasinda en yüksek örgütsel stres düzeyi ortaokullarda gerçekleşmiştir. Karadavut'a (2005) göre ise stres kaynaklarına en çok maruz kalan grup ilkokul ögretmenleridir. Sirke (2016, s. 71) ise okul kademesine göre anlamlı bir farklılık olmadığı görüşündedir. Canuylasi’nin (2020) örgütsel mutluluk ile ilgili yaptığı bir çalışmada en yüksek örgütsel mutluluk algısı, örgütsel stres algisının en düşük olduğu ilkokullarda; en düşük örgütsel mutluluk algısı ise en yüksek örgütsel stres algısının tespit edildiği liselerde tespit edilmiştir. Bu iki çalışma birbirini tamamlayan sonuçları ortaya koymaktadır.

Çalışmada okul müdürlerinin yıkıcı liderlik davranışlarının öğretmenler tarafindan "düs̆̈̈k" düzeyde algılandığı sonucuna ulaşılmıştır. Bir diğer tabirle okul müdürlerinin yıkıcı liderlik davranışları yaygınlık göstermemektedir. Öğretmenler, okul müdürlerinin yıkıc1 bir şekilde davranmadığını düşünmektedir. Aydınay'ın (2019, s. 129) yapmış olduğu çalışmada da "düşïk" bir düzeyden bahsedilebilir. Akman (2016, s. 644) ve Sezici ise (2015, s. 118) yıkıcı liderlik davranışlarının çalışanlar tarafindan "orta" düzeyde algılandığını tespit etmişlerdir.

Öğretmenlerin cinsiyetlerine göre yıkıcı liderlik algılarının ortalamasına bakıldığında ise anlamlı bir farklılık görülmemiştir. Erkek öğretmenlerin yıkıcı liderlik algıları ve kadın öğretmenlerin yıkıcı liderlik algıları, yıkıcı liderlik davranışlarının cinsiyete göre anlamlı bir farklılık oluşturmadığını göstermektedir. Bu sonuca göre yıkıcı liderlik davranışlarının erkek ve kadın öğretmenler üzerinde farklı algılanmadığı, cinsiyetin yıkıcı liderlik algısında önemli bir farklılık oluşturmadığı ortaya konmuştur. Bununla birlikte Woestman (2014, s. 84) çalışmasında kadın öğretmenlerin, erkek öğretmenlere göre, okul liderlerini daha yıkıcı algılama eğiliminde olduklarını tespit etmiştir. Güldü ve Aksu (2016, s. 108) kadınların erkeklere nazaran daha duyarlı olduğu ve yıkıcı liderlik algılarının daha yüksek olduğunu düşünmektedir. Akman (2016, s. 645) ise çalışmasında erkek öğretmenlerin kadın öğretmenlere göre okul müdürlerini daha yıkıc1 algıladıklarını belirtmiştir. Kimi araştırmalar kadınların, kimi çalışmalar erkeklerin daha fazla yıkıcı liderlik algısına sahip olduğunu göstermektedir. Cinsiyet baz alındığında özellikle ataerkil toplumlarda kadınların erkeklere göre çalışma hayatında ikinci planda olmaları nedeniyle daha fazla stres yaşadıkları düşünülebilir. Bunun yanında erkeklerin de özellikle erkin paylaşımı söz konusu olduğunda yöneticilerle daha fazla mücadeleye girdiğini söyleyebiliriz. Bu çalışmada ise cinsiyet açısından herhangi bir farklılı̆̆ın olmadığ1 ortaya konmuştur. Bunda cinsiyetçi yaklaşımların azalması, öğretmenlik mesleğinin icrasında cinsiyetin etkili bir faktör olmaması gibi sebeplerin etkili olduğu düşünülebilir.

Yıkıcı liderlik algısının eğitim durumuna göre farklılık gösterip göstermediğini ortaya koymak amacıyla yapılan diğer analizde ise eğitim durumuna göre anlamlı bir farklılık bulunamamışır. Eğitim durumu yıkıcı liderlik algısı üzerinde anlamlı bir farklılık yaratmamaktadır. Akman'ın (2016, s. 646) çalışması da paralel bulguları ortaya koymaktadır. Sezici (2015, s. 118) eğitim durumunun yıkıcı liderlik algısı üzerinde etkisi olduğunu ortaya koyan çalışmasında, lise ve meslek yüksekokulu mezunu çalışanların yıkıcı liderlik algisının, lisans ve lisansüstü mezunu olan çalsşanlara göre yüksek olduğunu tespit etmiştir.

Öğretmenlerin çalıştıkları okul kademelerine göre yıkıcı liderlik davranışlarının algıllanma düzeylerinin istatistiksel olarak farklılaştığı görülmektedir. Ortaokul ve lisede çalışan öğretmenler, ilkokulda çalışan öğretmenlere göre okul müdürlerini daha yıkıcı algilamışlardır. Bu sonuca bakıldığında ortaokul ve lisede çalışan öğretmenler okul müdürlerinin daha fazla yıkıcı lider davranışları sergilediğini düşünmektedirler. Akman (2016, s. 645) ise okul kademesine göre anlamlı bir farkllık belirtmese de okul kademesinin yükselmesiyle yıkıcı liderlik algısının yükseldiğini düşünmektedir. Literatürde bu bulguyu destekleyen başka bir çalışmaya rastlanılamamıştır. Okul kademesine göre ilkokul öğretmenlerinin yıkıcı liderlik algısının 
düşük olduğu görülmüştür. Ortaokul ve lisede çalşsan öğretmenler ise okul müdürlerini daha yıkıc1 alg1lamaktadirlar.

Araştırmanın bir diğer sonucuna göre öğretmenlerin kıdemine göre yıkıcı liderlik algıları farklılık göstermemiştir. Her ne kadar istatistiksel olarak anlamlı bir farklılık olmasa da özellikle meslekî kıdemi 5 yıl ve altında olanlar ile 21 yıl ve üzerinde olan öğretmenlerin yıkıcı liderlik puanlarının diğer gruplara göre düşük olduğu gözlenmiştir. $\mathrm{Bu}$ sonucun böyle çıkmasinda mesleğe yeni başlayan öğretmenlerin yöneticilerin yıkıcı liderlik davranışlarının farkında olmamaları, 21 yıl ve üzeri yıl kıdeme sahip öğretmenlerinde mesleki deneyim kazanmalarıyla yıkıcı liderlik davranışlarına maruz kalmamaları, okul yöneticilerinin 21 yıl ve üzeri kıdeme sahip öğretmenleri daha saygın bulmaları ve davranışlarının bundan etkilenmesi gibi etkenler etkili olmuş olabilir. Akman (2016, s. 645) ise ortaya koymuş olduğu çalışmada kıdemi 10 yıldan az olan öğretmenlerin yıkıcı liderlik algılarının, 10 yıl ve üzeri kıdeme sahip öğretmenlerin yıkıcı liderlik algılarından yüksek olduğunu belirtmiştir. Sezici $(2015$, s. 118) ise 1-5 yıl ve 6-10 yıl kıdeme sahip çalışanların yıkıcı liderlik algılarının, 11-15 yıl, 16-20 yıl ve 21 yıl ve üzeri kıdeme sahip çalışanlara göre yüksek olduğunu ortaya koymuştur. Çelebi’nin (2019, s. 122) çalışmasında yıkıcı liderlik algılarının çalışanların toplam çalışma sürelerine göre farklılaştığı görülmüsstür. 5 yıldan daha az toplam çalışma süresine sahip çalışanların 15 yıldan daha fazla çalışanlara göre yıkıcı liderlik algılarının daha düşük olduğu ifade edilmiştir.

Okul müdürlerinin yıkıcı liderlik davranışları ve örgütsel stres arasındaki korelasyon analizi sonuçlarına bakıldığında orta düzeyde ve pozitif yönde anlamlı bir ilişki olduğu görülmektedir. Okul müdürlerinin yıkıcı liderlik davranışlarının örgütsel stres düzeyini yordayıp yordamadığına ilişkin yapılan analiz sonucunda, yıkıcı liderlik davranışlarının örgütsel stresi \%17 oranında yordadığ sonucuna ulaşılmıştır. Diğer bir ifadeyle yıkıcı liderlik davranışları, örgütsel stresi etkilemektedir. Bu sonuçlara bakıldığında yıkıcı liderlik davranışlarının örgütsel stresi arttırdığ1 görülmektedir.

Khan vd. (2019, s. 141) yıkıcı liderliğin organizasyonlar içerisinde iş stresi, duygusal tükenmişlik ve düşük iş doyumuna sebep olduğunu ortaya koymuşlardır. Schmid vd. (2018, s. 2) yıkıcı liderlik davranışlarının, örgütte ve örgüt çalışanlarında birçok farklı dinamiği etkileyebileceğini belirtmişlerdir. Eğitim örgütleri açısından ele alındığında ise yıkıc1 liderlik, öğretmenlerin etkili öğretme düzeyini buna bağlı olarak da öğrencilerin etkin öğrenme firsatlarını ortadan kaldırmaktadır (Woestman ve Wasonga, 2015, s. 159). Sezici'ye göre (2015, s. 118) yıkıcı liderlik ve iş tatmini değişkenleri ele alındığında negatif bir iliş̧kiden bahsedilebilir. Ulaşılan bir başka sonuç ise yıkıcı liderlik ile iş stresi arasında pozitif yönde bir ilişki olduğu bilgisidir. Güldü ve Aksu'ya göre (2016, s. 108) yıkıcı liderlik alg1sı ve alt boyutlan, mesleki tükenmişlik ve duygusal tükenme arasında pozitif yönde anlamlı bir ilişki olduğu saptanmıştır. Kızıldaş (2017, s. 92) yapmış olduğu çalş̧mada karanlık lider ve iş performansı arasında pozitif bir ilişkinin olduğunu belirtmiştir. Öğretmenlerin yıkıcı liderlik algıları ile mesleki tükenmişlik düzeyleri arasında anlamlı pozitif bir ilişki olduğu tespit edilmiştir (Akman, 2016, s. 646). Liderin yıkıcı olan tutumları, etik olmayan davranışları da kapsamaktadır. Akan vd. (2014) yıkıcı liderlerin etik dışı davranışları sergilediği düşüncesinden yola çıkarak, etik olmayan davranışların örgütsel sinizme pozitif yönde etki edeceği sonucuna ulaşmıştır. Burroughs'un (2001'den akt., Çelebi, 2019, s. 122) çalısmalarında adam kayırma ve sık olmasa da sergilenen şiddet içerikli davranışlar yıkıcı liderin davranış türlerinden olmakla beraber, bu yıkıcı davranışların örgütsel sapmayı anlamlı ve pozitif yönde etkilediği sonucuna ulaşılmış̧ır. Uzun'a (2011, s. 182) göre örgütsel stres ile normatif bağll1ık arasında anlamlı negatif bir ilişki sonucuna ulaşılmıştır.

Yapılan çalışmalar örgüt çalışanlarının yıkıcı liderlik algılarını ortaya koymaktadır. Aasland vd., (2010, s. 438) çalışanların \%33 ila \%60’’ düzenli bir şekilde yıkıcı liderlik davranışına maruz kaldığını belirtirken, çalışanların \%40’1 herhangi bir yıkıcı liderlik davranışı algısının olmadığını ortaya koymuştur. Aravena'nın (2019, s. 92) Şili'de yapmış olduğu araştırmada ise katılımcıların \%49'u yıkıcı bir okul müdürüyle çalıştıklarını düşünmektedir. Türkiye'de Sezici (2015, s. 117) tarafından yapılan çalışmada ise katılımcıların yaklaşık \%42'si yıkıcı liderlik davranışlarına maruz kaldığını belirtmiştir. Yıkıcı liderliğin örgütsel stres üzerindeki etkisinin ortaya konmasını amaçlayan bu çalışmanın belki de en önemli sonuçlarından birisi de yıkıcı liderlik davranışlarının okulun her yerinde ve eğitimin her safhasında paydaşların karşısına çıkabileceğidir. Örgütsel stresin tetikleyicisi olan yıkıcı lider davranışları tanımlanmaya muhtaçtır. Örgüt çalışanının yıkıcı lider davranışlarını fark edebilmesi, lider davranışlarının tanımlanabilmesi ve sınıflandırılabilmesi için yıkıcı liderlik ile ilgili nicel ve nitel araştırmaların artması gerekmektedir. Alan yazın incelendiğinde yıkıcı liderlik fenomeni ile ilgili nitel araştırmaların oldukça kısıtlı olduğu görülmüştür. $\mathrm{Bu}$ sebeple yıkıcı liderlik ile ilgili nitel analizlerin yer aldığı bir araştırma yapılabilir. 


\section{Etik Beyan}

"Okul Müdürlerinin Yıkıcı Liderlik Davranışlarnm Örgütsel Strese Etkisi” başlıklı çalışmanın yazım sürecinde bilimsel, etik ve alıntı kurallarına uyulmuş; toplanan veriler üzerinde herhangi bir tahrifat yapılmamıs ve bu çalışma herhangi başka bir akademik yayın ortamına değerlendirme için gönderilmemiştir. Gerekli olan etik kurul izinleri Sabahattin Zaim Üniversitesi Etik Kurulu'nun 29.05.2020 tarih ve 2020/05 sayll toplantısında alınmıştır.”

\section{Kaynakça}

Aasland, M. S., Skogstad, A., Notelaers, G., Nielsen, M. B. ve Einarsen, S. (2010). The prevalence of destructive leadership behaviour. British Journal of management, 21(2), 438-452.

Aslan, M., ve Bakıı, A. A. (2018). Sınıf öğretmenlerinin yaşadıkları örgütsel stres kaynakları. Cumburiyet Uluslararası Ë̈itim Dergisi, 7(4), 349-365.

Akan, D., Bektaş, F. ve Yıldırım, İ. (2014). Sınıf öğretmeni algılarına göre etik liderlik ve örgütsel sinizm arasındaki ilişki. E-Journal of New World Sciences Academy, 605.

Akgemci, T. (2001). Örgütlerde stres ve yönetimi. Atatürk Üniversitesi İktisadi ve İdari Bilimler Dergisi, 15(1-2).

Akman, Y. (2016). Yıkıcı lider ile mesleki tükenmişlik arasındaki ilişki: Öğretmenler üzerine bir araştırma. Eğitimde Kuram ve Uygulama Dergisi, 12(3), 622-648.

Aksay, B. ve Güğgerçin U. (2016). Yıkıcı yönetimin izlenim yönetimi taktikleri üzerindeki etkisi: beyaz yakalı çalışanlar üzerine bir araştırma. C..Ü. Sosyal Bilimler Enstitiisï Dergisi, 25(3): 441-456.

Aravena, F. (2019). Destructive leadership behavior: An exploratory study in Chile. Leadership and policy in schools, 18(1), 83-96.

Ashforth, B. (1994). Petty tyranny in organizations. Human relations, 47(7): 755-778.

Aslan, M. ve Bakır, A. A. (2018). Sınıf öğretmenlerinin yaşadıkları örgütsel stres kaynakları. Cumburiyet Uluslararası Eğitim Dergisi, 7(4): 349-365.

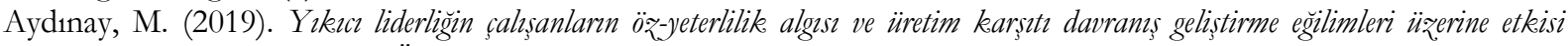
(Doktora Tezi). Mersin Üniversitesi, Sosyal Bilimler Enstitüsü, Mersin.

Bass, B. M. ve Stogdill, R. M. (1990). Stogdill's handbook of leadership: Theory, research, and managerial applications. Simon and Schuster.

Başar, U., Sığrı, Ü. ve Basım, N. (2016). İss yerinde karanlık liderlik. Isş ve Insan Dergisi , 3 (2), 65-76.

Başaran, İ. E. (1991). Örgütsel davranış. Gül Yayınevi: Ankara.

Baytak, Ö. (2015). Ögretmen algzlarnna göre okul müdürlerinin mükemmeliyetçilik düzeyleri ile ögretmenlerin örgütsel stres düreyleri arasindaki iliski (Şanlunfa ili örneği) (Yüksek Lisans Tezi). Zirve Üniversitesi, Sosyal Bilimler Enstitüsü, Eğitim Yönetimi, Teftişi, Planlaması ve Eko. Ana Bilim Dalı, Gaziantep.

Cemaloğlu, N. (2007). Örgütlerin kaçınılmaz sorunu: Yıldırma. Bilig, 42, 111-126.

Chen, C. Y., Mao, H. Y., Hsieh, A. T., Liu, L. L. ve Yen, C. H. (2013). The relationship among interactive justice, leader-member exchange, and workplace friendship. The Social Science Journal, 50(1), 89-95.

Conger, J. A. (1990). The dark side of leadership. Organizational dynamics, 19(2), 44-55.

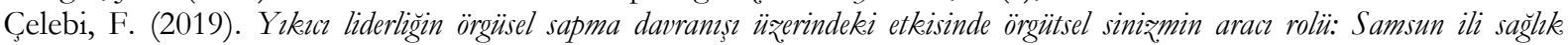
sektöründe bir arasttrma (Doktora Tezi). Ondokuz Mayıs Üniversitesi, Sosyal Bilimler Enstitüsü, Samsun.

Çelebi, N., Güner, A. G. H. ve Yildiz, V. (2015). Toksik liderlik ölçeğinin geliştirilmesi. Bartın Üniversitesi Eğitim Fakültesi Dergisi, 4(1), 249-268.

Çelik, A., ve Şimşek, M. Ş. (2013). Yönetim ve organizasyon. Eğitim Yayınevi.

Dak, G. (2019). Millî Eğitim Bakanlğg taşra örgütündeki üst düzey yöneticilerin algzlarna göre kadm yöneticilerin liderlik davranıslar ve ögretmenlerin örgütsel stres düzeyleri (Yüksek Lisans Tezi). Çanakkale Onsekiz Mart Üniversitesi, Çanakkale.

Einarsen, S., Aasland, M. S., \& Skogstad, A. (2007). Destructive leadership behaviour: A definition and conceptual model. The Leadership Quarterly, 18(3), 207-216.

Eriş, Y. C. ve Yücel, R. (2018). Örgütsel stres ve örgütsel stresle başa çıkma yöntemleri: İstanbul'da bir perakende mağazası ve şubelerinde araştırma. Kesit Akademi Dergisi, (17), 314-331.

Ertekin, Y. (1993). Stres ve yönetim. Türkiye ve Orta Doğu Amme İdaresi Enstitüsü, Ankara.

Gök, S. (2009). Çalışma yaşamının önemli bir sorunu: örgütsel stres. Marmara Üniversitesi İktisadi ve İdari Bilimler Dergisi, 27(2), 429-448.

Güldü, Ô. ve Aksu, N. E. (2016). Yıkıcı liderlik alg1sı ve mesleki tükenmişlik arasındaki ilişkide olumsuz duygudurumun aracı rolü. Çalssma İliskileri Dergisi, 7(2), 91-113.

Gündüz, Y. ve Dedekorkut, S. (2014). Yıkıc1 liderlik. Mersin Üniversitesi Eğitim Fakültesi Dergisi, 10(1).

Harris, K. J., Kacmar, K. M. ve Zivnuska, S. (2007). An investigation of abusive supervision as a predictor of performance and the meaning of work as a moderator of the relationship. The leadership quarterly, 18(3), 252-263.

Holmquist, D. B. (2017). Hosea 7: 1-16 and destructive leadership theory: An exegetical study. Production Staff, 10(1), 126-17. 
Howell, J. M. ve Avolio, B. J. (1992). The ethics of charismatic leadership: submission or liberation?. Academy of Management Perspectives, 6(2), 43-54.

Iş1khan, V., (2004). In work life stres (in Turkish). Ankara: Sandal Yay.

James, L. ve LeBerton, J. M. (2010). Assessing aggression using conditional reasoning. Current Directions in Psychological Science, 19(1), 30-35.

Karadavut, Y. (2005). Ilkögrretim okulu ögretmenlerinin örgütsel stres kaynaklar, stres belirtileri ve stresle başa çlkma yollar (Yüksek Lisans Tezi). Gazi Üniversitesi, Ankara.

Khan, N. Z. A., Imran, A. ve Anwar, A. (2019). Destructive leadership and job stress: Causal effect of emotional exhaustion on job satisfaction of employees in call centers. International Journal of Information, Business and Management, 11(1), 135-142.

Kelloway, E. K., Sivanathan, N., Francis, L. ve Barling, J. (2005). Poor leadership. Handbook of work stress, 89-112.

Kızıldaş, E. (2017). Kültürel değerlere göre karanlık lider algısınm çalısan is performansı etkisi üzerine bir araştırma (Yüksek Lisans Tezi). Başkent Üniversitesi, Sosyal Bilimler Enstitüsü, Ankara.

Lewig, K. A. ve Dollard, M. F. (2001). Social construction of work stress: Australian Newsprint Media portrayal of stress at work. Work \& Stress, 15(2), 179-190.

Lipman-Blumen, J. (2005). Toxic leadership: When grand illusions masquerade as noble visions. Leader to Leader, 2005(36), 29-36.

Lundmark, R., Nielsen, K., Hasson, H., von Thiele Schwarz, U. ve Tafvelin, S. (2020). No leader is an island: contextual antecedents to line managers' constructive and destructive leadership during an organizational intervention. International Journal of Workplace Health Management.

Merkan, S. (2011). Genel lise ve anadolu liselerinde görevli öğretmenlerin örgütsel stres kaynaklarmın karşılaștırmalı analizi: Malatya ili örneği (Yüksek Lisans Tezi). İnönü Üniversitesi Sosyal Bilimler Enstitüsü, Malatya.

Moğul, E. (2014). Öz̧el okullar ve devlet okullarnda çalışan ortaokul ögretmenlerinin örgütsel stres kaynaklarmmn karşılaştırmalı analiz̧i (Yüksek Lisans Tezi). İstanbul Sabahattin Zaim Üniversitesi, Sosyal Bilimler Enstitüsü, İstanbul.

Örnek, F., E. (2017). Örgütsel stresin isgören performansı üzerinde etkileri ve stres yönetimi: Kamu ve özel sektör bankacılĭg üzerine bir uygulama (Yüksek Lisans Tezi). Ufuk Üniversitesi, Sosyal Bilimler Enstitüsü, İstanbul.

Özbaş, F. (2019). Ögrretmenlerin örgütsel stres kaynaklar ve stres belirtileri ile is doyumlar arasindaki ilişkinin incelenmesi (Yüksek Lisans Tezi). Kahramanmaraş Sütçü İmam Üniversitesi, Sosyal Bilimler Enstitüsü, Kahramanmaraş.

Padilla, A., Hogan, R. ve Kaiser, R. B. (2007). The toxic triangle: Destructive leaders, susceptible followers, and conducive environments. The Leadership Quarterly, 18(3), 176-194.

Pehlivan, İ. (1993). Hizmet içi eğitim-verimlilik ilişkisi. Ankara Üniversitesi Eğitim Bilimleri Fakültesi Dergisi, 25(1), 151162.

Pehlivan, İ. (1998). Yönetsel mesleki ve örgütsel etik. Ankara: Pegem.

Poyraz, E. (2009). Illkögrretim ve ortä̈gretim okulu ögretmenlerin örgütsel stres kaynaklar ve stresle başa çlkma yollar (Yüksek Lisans Tezi). Yeditepe Üniversitesi, Sosyal Bilimler Enstitüsü, İstanbul.

Sarıaslan Eyiol, Ş. (2014). Okul yöneticilerinin yıkıcı yöneticilik davranısına yönelik ögrretmen algısı (Yüksek Lisans Tezi). Okan Üniversitesi, Bursa.

Schmid, E. A., Pircher Verdorfer, A. ve Peus, C. V. (2018). Different shades—different effects? Consequences of different types of destructive leadership. Frontiers in Psychology, 9, 1289.

Schyns, B. ve Schilling, J. (2013). How bad are the effects of bad leaders? A meta-analysis of destructive leadership and its outcomes. The Leadership Quarterly, 24(1), 138-158.

Selçuk, Ş. (2018). Yapıcı ve yıkıcı lider davramıslar ve ar-ge takımlarnda ögrenme üzerine etkisi (Doktora Tezi). Kocaeli Üniversitesi, Kocaeli.

Sevinçok, L. (2017). Örgütsel ve toplumsal yapılarda liderlik-otoriterlik. Karatabta Işs Yaz̧ılar Dergisi, 9, 135-166.

Sezici, E. (2016). İzleyicilerin yıkıcı liderlik alg1sı ve sonuçları. Dumlupınar Üniversitesi Sosyal Bilimler Dergisi, (47), 106121.

Sirke, Ç. (2016). Özel okul ögretmenlerinde örgütsel stres ve örgütsel özdeşleşme (Yayınlanmış Yüksek Lisans Tezi). Bahçeşehir Üniversitesi, İstanbul.

Skogstad, A., Hetland, J., Glasø, L. ve Einarsen, S. (2014). Is avoidant leadership a root cause of subordinate stress? Longitudinal relationships between laissez-faire leadership and role ambiguity. Work Stress, 28(4), 323-341.

Tepper, B. J. (2000). Consequences of abusive supervision. Academy of Management Journal, 43(2), 178-190.

Thoroughgood, C. N., Hunter, S. T. ve Sawyer, K. B. (2011). Bad apples, bad barrels, and broken followers? An empirical examination of contextual influences on follower perceptions and reactions to aversive leadership. Journal of Business Ethics, 100(4), 647-672.

Uymaz, A.O. (2013). Yıkıcı liderlik ölçeği geliştirme çalışması. Isşletme Fakültesi Issletme İktisat Enstitüsü Yönetim Dergisi, 24(75), 37-57.

Uzun, Ö. (2011). Örgütsel stres ve örgütsel bağlllık ilişkisi üzerine orta kademe ve otel yöneticileri üzerinde yapılan bir araştırma. Eskişehir Osmangą̧ Üniversitesi İIBF Dergisi, 6(1), 181-213.

Westen, D. (1998). The scientific legacy of Sigmund Freud: Toward a psychodynamically informed psychological science. Psychological Bulletin, 124(3), 333-371.

Wilson-Starks, K. Y. (2003). Toxic leadership. Transleadership, Inc, 1, 2016.

Woestman, D. S. (2014). Destructive leader behavior: Assessing public school leader behaviors and workplace attitudes. 
Woestman, D. S. ve Wasonga, T. A. (2015). Destructive leadership behaviors and workplace attitudes in schools. NASSP Bulletin, 99(2), 147-163.

Yaman, M. (2019). Örgütsel stresin çalısan performansı üzerine etkisi: Özel sektör banka çalışanlar üzerinde bir araştırma (Yüksek Lisans Tezi). Beykent Üniversitesi, Sosyal Bilimler Enstitüsü, İstanbul.

Yıldırım, Y., Taşmektepligil, M. Y. ve Üzüm, H. (2011) Kısa versiyon örgütsel stres ölçeğinin türkçeye uyarlanması (Geçerlilik ve güvenirlik Çalışması). Selcuk Üniversitesi Beden Eğitimi ve Spor Bilim Dergisi,13(1), 103-108.

Yolbakan, E. (2019). Özel okullarda görev yapan ögretmenlerin örgütsel stres düzeyleri ile mesleki performanslar arasindaki iliskiAydın ili Efeler ilçesi örneği (Yüksek Lisans Tezi). Aydın Adnan Menderes Üniversitesi, Sosyal Bilimler Enstitüsü, Eğitim Bilimleri Ana Bilim Dalı, Eğitim Yönetimi ve Teftişi Bilim Dalı, Aydın.

Yukl, G. (1989). Managerial leadership: A review of theory and research. Journal of management, 15(2), 251-289.

\section{EXTENDED ABSTRACT}

In the historical processes of Management Science, the concepts of leader and leadership have a very important place, as well as descriptions made from different angles. Leadership 20. it has become a phenomenon with numerous studies on leadership in the century (Erçetin, 2000). Bass and Stogdill have noted that much work on leadership is available, and many researchers have repeatedly taken up leadership (Bass and Stogdill, 1990). Yukl (1989), he defined leadership as directing the activities of the group to achieve a common goal, as a force of influence that he creates on the people who make up the group, with no compelling purpose. Disruptive leader behaviours are defined as regular and repetitive leader behaviours that reduce the organization's goals, the resources it has, and the welfare level of the business and do not avoid neglecting or violating the organization's interests (Einarsen, 2007). According to Conger (1990) when the leader acts in an effort of personal gain, he damages his employees and the organization. Disruptive leadership has two main problems, the first being that the consequences and costs of distuptive leadership behaviour are severe, and the second is that disruptive leadership is widespread in powerful institutions (Schyns, Schilling, 2012). Stress, which covers stress sources and attitudes involving tension in the work environment and becomes a social reality, refers to the mismatch between the work environment and the worker (Lewig and Dollard, 2001). Organizational stress begins with the perception of various situations and events in the organizational environment as a source of stress by the employee (Ertekin, 1993). The main problem that causes the efficiency of the organization to decrease can be considered to be stress (Cemaloğlu, 2007). Roles whose lines are unclear, the distribution of roles in the conflict, the more or less workload, the lack of an intelligible language of communication, a Career Management whose influence is dispersed, professional differences and performance measurements can be listed among the factors that constitute stress (Akgemci, 2001). When we consider disruptive leader behaviour, it can be considered to have a strong link with the factors that make up organizational stress. To determine the existence of a leader who acts in a destructive nature, the people who make up the organization need to recognize these behaviours (Uymaz, 2013). Individuals subjected to disruptive leader behaviour engage in disruptive activities through ruined identity psychology. This research is a study that examines the impact of disruptive leadership behaviour by school principals on teachers ' organizational stress. For this purpose, the relational scanning model was preferred. In the 20192020 academic year, 4235 teachers are employed in public schools in Tuzla District of Istanbul province. The sample of the study was selected by cluster sampling among teachers working in primary, secondary and high schools in Tuzla District of Istanbul. The sample consisted of 450 teachers selected by the cluster sampling method. The data was collected with the help of the "distuptive leadership Scale" developed by Uymaz (2013) and the "organizational stress scale" adapted to Turkish by Yildirim et al (2011). The data collected were analyzed using t-test, Anova, correlation and regression tests. It has been investigated whether disruptive leadership behaviours and perceptions of organizational stress differ in different variables such as gender, educational level, school rank, and professional seniority. According to the initial findings of the study, teachers ' organizational stress level was 'moderate' and their disruptive leadership level was 'low'. As a result of the research, teachers in middle school and high school perceived school principals as more disruptive leaders than primary school teachers. Perceptions of disruptive leadership did not differ significantly according to the gender, level of education and seniority of teachers. High school teachers ' perceptions of organizational stress were found to be higher than those of elementary school teachers. The organizational stress level of teachers with 5 years and less working time was lower than the organizational stress levels of teachers working 6-10, 11-15, 16-20, 21 and above years. A moderate positive relationship was found between disruptive leadership and organizational stress. Also, 
disruptive leadership behavior predicts organizational stress by $17 \%$. Perhaps one of the most important results of this study, which aims to demonstrate the impact of disruptive leadership on organizational stress, is that disruptive leadership behaviours can come before stakeholders everywhere in school and at every stage of education. disruptive leader behaviors that trigger organizational stress need to be defined. For the employee of the organization to be able to recognize disruptive leader behaviors and to be able to identify and classify leader behaviors, quantitative and qualitative research on disruptive leadership needs to be increased. When the field was examined, qualitative research on the phenomenon of disruptive leadership was found to be quite limited. Therefore, research involving qualitative analyses of disruptive leadership can be conducted. 